\title{
The rumen as a health thermometer: importance of ruminal function to the metabolic balance in ruminants - mini review
}

\begin{abstract}
The importance of ruminants supporting the man has been explored since the beginning of the 20th century. Recent concerns have shown that to attend the future demand of animal protein for the next 30 years is necessary to increase production in more than double by 2050 . Throughout the centuries intense changes in ruminant diets forced animals to develop adaptations of feed behavior and morphological modifications on digestion, inducing drastic modifications to the future evolutionary adaptations of ruminant digestive system and increasing the risk of ruminal/metabolic diseases. Studies of the relationships between behavior and animal health have raised debates of how to identify ill animals using approaches that measures rumination time to predict risk of metabolic disorders in a herd. Therefore, the analysis of behavioral elements as the rumination time could be used as a marker to foresee animals at risk of diseases, and as a first step to apply preventive veterinary practices in ruminant herds.
\end{abstract}

Keywords: ruminal physiology, rumination time, metabolic diseases, negative energy balance, feed behavior
Volume 5 Issue 3 - 2017

\section{Saulo Gusmão da Silva de Tarso}

Centro Universitário Cesmac, Brazil

\begin{abstract}
Correspondence: Saulo Gusmão da Silva de Tarso, Clínica e Hospital Escola de Medicina Veterinária, Centro Universitário Cesmac, Rodovia Divaldo Suruagy, S/N. Quadra 04, Marechal Deodoro,AL 57.160-000, Brazil, Email stdetarso@hotmail.com
\end{abstract}

Received: February 26, 2017 | Published: April 24, 2017
Abbreviations: HC, high concentrate; RT, rumination time; DMI, dry matter intake; NEB, negative energy balance

\section{The role of ruminants on global food system}

Since the beginning of the $20^{\text {th }}$ century manuscripts explore the importance of ruminants supporting the $\operatorname{man}^{1,2}$ and as a major global element in agricultural economy. ${ }^{3-5}$ Recent studies have predicted that to reach the future demand of animal protein for the next 30years, it is necessary to increase animal protein production in more than double by $2050 .^{6-8}$ Recently we have reviewed ruminant adaptations and evolution throughout the centuries and the new scenario of diets provoking morphological changes in the digestion and feed behavior in domestic ruminants. ${ }^{9}$ Hence, this new situation indicates that feeding a long-term high-concentrate (HC) diet, induces cellular damage on both ruminal and colonic epithelium in goats, ${ }^{10}$ and in genes that regulate thickness of the ruminal epithelium in cows. ${ }^{11}$ Therefore, despite the fact that dietary changes and nutritional shifts can increase the chance of ruminal/metabolic diseases, and may cause more drastic modifications to the future evolutionary adaptations of ruminant digestive system, ${ }^{9,12}$ new approaches of evaluating ruminal behavior may be a strong marker to predict the risk of diseases and suitable herd welfare. ${ }^{13-16}$ Hence, this review aims to provide recent information of the associations between ruminal behavior and metabolic disorders. In addition, show the relations among the new approaches of monitoring ruminal function, predicting the risk of diseases.

\section{Variables that can influence rumination}

The rumination process is essential to fore stomach animals as the key event to keep a perfect function of the pre-stomachs. This process works not only to break down fiber in forage feeds, but also to maintain several aspects of metabolic balance as; the ideal ruminal $\mathrm{pH}$, ruminal turnover, re-absorption of nitrogen through the urea cycle, and as a sensible measurement of acceptable herd welfare..$^{13,17,18}$ Rumen motility can be divided into primary contractions, which affect the whole reticulorumen, and secondary movements, which affect only a part of the organ. The ruminal motions depends on the activity of the animal, whether eating, ruminating or resting, and it requires up to 50seconds to complete a total cycle. ${ }^{18}$ The variability of negative influences in the normal functioning of the rumination process is caused by many factors including acute stress, ethological behavior, diet quality and composition, production level, climatic condition, reproduction and health status. ${ }^{19-22}$ These variables can cause metabolic changes as a response, including reduction in blood flow to rumen epithelium and diminished rate of digesta in the gastrointestinal tract. ${ }^{22-24}$ In cases of indigestible residues, reticulorumen mixing and rumination together promote its turnover, which, if allowed to accumulate, would clot the rumen. The consequence of these changes is a depression of rumination time (RT), which subsequently leads to a reduction of dry matter intake (DMI), followed by a decline in weight gain or milk yield. ${ }^{18,25}$ These conditions when occurring in transition dairy cows, can result in a prolonged decrease in DMI around calving and may result in nonadaptive negative energy balance (NEB), which may lead to diseases related to the transitional period as subclinical ketosis, hypocalcemia, displaced abomasum, retained fetal membranes, and metritis. ${ }^{14,26}$

\section{Rumination behavior and metabolic condi- tions}

The associations among ruminal motions and metabolic disorders are progressively more intense as these circumstances are near to pregnancy. Reproduction status plays a pivotal role in diminishing the DMI as the transition period begins, dictating how intense and adaptable will be the NEB..$^{13,14,26}$ In small ruminants, the high prolific rate increases the risk of energy imbalance during the pre and post-partum, and the sum of a limited physical space in the pregnant abdomen, reduced DMI during this period, and changes to a $\mathrm{HC}$ diets are factors that limit and lessen rumen cycles. ${ }^{19,27,28}$ Our 
clinical observations during cesarean sections in obese sheep indicate evidences of a slight reduction on reticulorumen space in the abdomen due to the great amount of adipose tissue. During the left paralumbar fossa celiotomy and after gaining access to the abdomen, it was noted that the left flank has been partially taken by a portion of the duodenum covered by an extremely fat greater omentum. Despite the fact that obese condition directly affects glucose and insulin efficiency and increase the risk of metabolic disorder, the effects of a shrunken ruminal space due to accumulated fat in the abdomen raises a red flag on ruminal adaptations due to long-term HC diets. ${ }^{9,29}$

\section{Measurements of cow behavior identify ani- mals at risk for illness}

Currently, studies of animal behavior are gaining attention because of the relationships between behavior and animal health. Debates of how to predict and identify ill animals in a herd, and how to apply preventive veterinary practices are active topics of research. ${ }^{16}$ After the indications that rumination behavior may be a promising indicator of metabolic conditions, new methods to measure and evaluate herd performance have typically focused on feeding comportment in ruminants..$^{30}$ Therefore, the introduction of a novel method to indirectly measure RT, evaluates vocal signs and allows automatic measurement of RT to analyze rumination behavior in different environments. ${ }^{13,22}$ Results of these studies found that cows with different health problems ruminate less then healthy cows, and therefore, there is a relationship between RT and metabolic conditions such as ketosis, hypocalcemia, and inflammatory blood markers around calving. . $13,14,22,30^{2}$

\section{Conclusion}

The importance of ruminal cycling and motion is imperative not only for the animal's digestive physiology, but also as a function driven by the entire health status. The analysis of behavioral elements as the rumination time could be used as a marker to predict animals at risk of diseases, and as a first step to apply preventive veterinary practices in ruminant herds.

\section{Acknowledgement}

None.

\section{Conflict of interest}

Author declares that there is no conflict of interest.

\section{References}

1. Fitzhugh HA, Hodgson HJ, Scoville OJ, et al. The role of ruminants in support of man. Winrock International. Morrilton, USA; 1978. p. 139

2. Hungate RE, Phillips GD, Mcgregor A, et al. Microbial fermentation in certain mammals. Science. 1959;130(3383):1192-1194.

3. Mario Herrero, Philip K Thornton. Livestock and global change: emerging issues for sustainable food systems. Proceed of the National Academy of Science of the United States of America. 2013;110(52):20878-20881.

4. Herrero M, Thornton PK, Gerber P, et al. Livestock, livelihoods and the environment: understanding the trade-offs. Current Opinion in Environmental Sustainability. 2009;1(2):111-20.

5. Godfray HC, Crute IR, Haddad L, et al. The future of the global food system. Philos Trans R Soc Lond B Biol Sci. 2010;365(1554):2769-2777.

6. Christopher Delgado, Mark Rosegrant, Henning Steinfeld, et al. Livestock to 2020: the next food revolution. Outlook on Agriculture. 2001;30(1):27-29.
7. Nikos Alexandratos, Jelle Bruinsma. World agriculture towards 2030/ 2050. The 2012 revision. FAO. 2012: 3-12p.

8. Stefano Gerosa, Jakob Skoet. Milk availability Trends in production and demand and medium-term outlook. FAO, Agricultural Development Economics Div. 2012;12(1):1-40.

9. de Tarso SGS, Ovliveira D, Afonso JAB. Ruminants as Part of the Global Food System: How Evolutionary Adaptations and Diversity of the Digestive System Brought them to the Future. J Dairy Vet Anim Res. 2016;3(5):1-7.

10. Steele MA, Vandervoort G, AlZahal O, et al. Rumen epithelial adaptation to high-grain diets involves the coordinated regulation of genes involved in cholesterol homeostasis. Physiol Genomics. 2011;43(6):308-316.

11. Steele MA, Croom J, Kahler M, et al. Bovine rumen epithelium undergoes rapid structural adaptations during grain-induced subacute ruminal acidosis. Am J Physiol Regul Integr Comp Physiol. 2011;300(6):R1515$\mathrm{R} 1523$.

12. Clauss M, Lechner-Doll M, Streich WJ. Ruminant diversification as an adaptation to the physicomechanical characteristics of forage. A reevaluation of an old debate and a new hypothesis. Oikos. 2003;102(2):253-262.

13. Calamari L, Soriani N, Panella G, et al. Rumination time around calving : An early signal to detect cows at greater risk of disease. J Dairy Sci. 2014;97(6):3635-3647.

14. Kaufman EI, Leblanc SJ, Mcbride BW, et al. Association of rumination time with subclinical ketosis in transition dairy cows. J Dairy Sci. 2016;99(7):5604-5618.

15. Almeida PE, Weber PSD, Burton JL, et al. Depressed DHEA and increased sickness response behaviors in lame dairy cows with inflammatory foot lesions. Domest Anim Endocrinol. 2008;34(1):89-99.

16. Weary DM, Huzzey JM, Keyserlingk MAG Von. Using behavior to predict and identify ill health in animals. J Anim Sci. 2009;87(2):770-777.

17. Dirksen G, Grunder HD, Stober M. Sistema digestivo. Rosemberger exame clínico dos Bov. 10th ed. Rio de Janeiro, Brazil: Guanabara Koogan; 1993. p. 166-228.

18. Van Soest PJ. Nutritional ecology of the ruminant. 2nd ed. New York: Cornell University Press; 1994

19. Hansen SS, Norgaard P, Pedersen C, et al. The effect of subclinical hypocalcaemia induced by Na2EDTA on the feed intake and chewing activity of dairy cows. Vet Res Commun. 2003;27(3):193-205.

20. Welch JG. Rumination, particle size and passage from the rumen. J Anim Sci. 1982;54(4):885-894.

21. Herskin MS, Munksgaard L, Ladewig J. Effects of acute stressors on nociception, adrenocortical responses and behavior of dairy cows. Physiol Behav. 2004;83(3):411-420.

22. Soriani N, Panella G, Calamari L. Rumination time during the summer season and its relationships with metabolic conditions and milk production. J Dairy Sci. 2013;96(8):5082-5094.

23. Hales JRS, Bell a W, King RB, et al. Redistribution of cardiac output and skin AVA activity in sheep during exercise and heat stress. $J$ Therm Biol. 1984;9:113-116.

24. Silanikove N. Effects of water scarcity and hot environment on appetite and digestion in ruminants: a review. Livest Prod Sci. 1992;30:175-94.

25. Moallem U, Altmark G, Lehrer H, et al. Performance of high-yielding dairy cows supplemented with fat or concentrate under hot and humid climates. J Dairy Sci. 2010;93(7):3192-3202.

26. Drackley JK. Biology of Dairy Cows During the Transition Period : the Final Frontier? J Dairy Sci. 1999;82(11):2259--2273. 
27. Linklater AF, Smith MC. Metabolic diseases and nutritional deciciencies. Color Atlas Dis. Disord. Sheep Goat. USA: Mosby-wolfe; 2000. p. 210-218.

28. Smith MC, Sherman DM. Goat medicine. 2nd ed. Ames, IA, USA Blackwell publishing; 2009.
29. Regnault TRH, Oddy HV, Nancarrow C, et al. Glucose-stimulated insulin response in pregnant sheep following acute suppression of plasma nonesterified fatty acid concentrations. Reprod Biol Endocrinol. 2004;2:64.

30. Soriani N, Trevisi E, Calamari L. Relationships between ruminantion time, metabolic conditions, and health status in dary cows during the transition period. J Anim Sci. 2012;90(12):4544-4554. 